\title{
Pathogen-derived resistance using a viral nucleocapsid gene confers only partial non-durable protection in peanut against peanut bud necrosis virus
}

\author{
S. Chander Rao $\cdot$ P. Bhatnagar-Mathur $\cdot$ \\ P. Lava Kumar • A. Sudarshan Reddy • \\ Kiran K. Sharma
}

Received: 9 April 2012/ Accepted: 9 August 2012/Published online: 26 September 2012

(C) Springer-Verlag Wien 2012

\begin{abstract}
Genetic engineering of peanut (Arachis hypogaea L.) using the gene encoding for the nucleocapsid protein ( $\mathrm{N}$ gene) of peanut bud necrosis virus (PBNV; genus Tospovirus, family Bunyaviridae) was used to impart resistance to bud necrosis disease in peanut (PBND), a disease for which no durable resistance is available in the existing germplasm. Over 200 transgenic lines of peanut var. JL 24 were developed for which integration and expression of the transgenes was confirmed by PCR, Southern hybridization, RT-PCR and western blot analysis. The $\mathrm{T}_{1}$ and $\mathrm{T}_{2}$ generation transgenic plants were assayed through virus challenge in the greenhouse by using mechanical sap inoculation at 1:100 and 1:50 dilutions of PBNV, and they showed varying levels of disease incidence and intensity. Greenhouse and field evaluation with $\mathrm{T}_{2}$ generation plants indicated somewhat superior performance of the three transgenic events that showed considerable reduction in disease incidence. However, only one of these events showed over $75 \%$
\end{abstract}

Electronic supplementary material The online version of this article (doi:10.1007/s00705-012-1483-8) contains supplementary material, which is available to authorized users.

\section{Present Address:}

S. C. Rao

Directorate of Oilseeds Research (DOR), Rajendranagar,

Hyderabad 500 030, India

P. Bhatnagar-Mathur · A. S. Reddy · K. K. Sharma $(\bowtie)$ Genetic Transformation Laboratory, International Crops Research Institute for the Semi-Arid Tropics (ICRISAT), Patancheru, Hyderabad 502 324, India

e-mail: k.sharma@cgiar.org

Present Address:

P. L. Kumar

International Institute of Tropical Agriculture (IITA),

Oyo Road, PMB 5320, Ibadan, Nigeria reduction in disease incidence when compared to the untransformed control, indicating partial and non-durable resistance to PBND using the viral N-gene.

\section{Introduction}

Peanut (Arachis hypogaea L.) is a popular legume crop, cultivated in over 100 countries across the six continents as a rich source of edible oil (43-55\%), protein (23-28\%) and carbohydrates (10-15\%). With an annual world production of 37.2 million tons from 23.4 million ha, peanut is a major oilseed crop that is grown commercially throughout the tropical, subtropical and warm temperate regions of the world [20]. It is largely a small-holder crop, grown under rainfed conditions in semi-arid areas characterized by unpredictable rainfall, and these areas contribute over $90 \%$ of world peanut production. The low yields of peanut are primarily due to low inputs, rainfed cultivation of the crop in marginal lands, non-availability of seed of suitable high-yielding varieties, and the occurrence of many insect pests, fungal diseases, and numerous viral diseases at different stages of crop growth.

Peanut bud necrosis virus (PBNV) is a member of the genus Tospovirus, which includes arthropod-borne, plantinfecting members of the family Bunyaviridae [26], and it is transmitted by thrips (Thrips palmi Karmy) in a persistent manner [38]. PBNV is economically important in South and Southeast Asian countries, including India, Nepal, Sri Lanka, Myanmar, Thailand and parts of China [25]. The disease incidence has been reported to be up to $50 \%$ in major peanut-growing areas and causes yield losses of over $80 \%$ in the early infected crop [24]. Control of this virus through cultural practices such as crop rotation, chemical control of thrips vectors, and removal of alternate weed 
hosts have met with limited success. Hence, the development of virus-resistant host plant varieties is the most promising means of controlling virus diseases in the long term. At the International Crops Research Institute for the Semi-Arid Tropics (ICRISAT), although over 8,000 germplasm accessions have been evaluated to identify resistance to PBNV, durable resistance has not been found, with the exception of a few lines that were moderately resistant to the vector [7]. While members of a few wild species of the genus Arachis have shown good levels of resistance to PBNV, they are sexually incompatible with the cultivated varieties and have low yields [1]. Thus, it has become imperative to look for alternative approaches, and one of the best possible options is the development of PBNV-resistant transgenic peanut plants. Genetically engineered resistance has been actively investigated in recent years as an attractive option [15]. Expression of virus-derived genes in transgenic host plants has been shown to result in reduced susceptibility of the plant to virus infection, and the degree of protection has ranged from a delay in symptom expression to absence of symptoms and virus accumulation [10]. The gene encoding the nucleocapsid protein $(\mathrm{N}$ gene) of viruses has been used extensively to impart disease resistance in various crop plants, and the resistance acquired was correlated either to an RNA-mediated mechanism or high N protein accumulation [8, 13, 22, 34]. Transgenic peanut plants have previously been developed for resistance to various viral diseases by using the viral coat protein and/or replicase genes $[5,6,11,15,30]$. Although the use of the $\mathrm{N}$ gene of PBNV has been demonstrated in Nicotiana tabacum [37], there are no reports on the development and evaluation of transgenic peanut plants for conferring resistance to PBND. Considering the importance and scope of PBND, the present research work was undertaken to develop and evaluate transgenic peanut plants using the viral $\mathrm{N}$ gene for pathogen-derived resistance against PBNV.

\section{Materials and methods}

\section{Plasmid constructs}

The $\mathrm{N}$ gene of PBNV (ICRISAT isolate), consisting of 831 nucleotides and encoding a protein of 276 amino acids with a predicted molar mass of $30.6 \mathrm{kDa}$, was sequenced and cloned in pGEM5Z [28]. The plasmid pGEM5Z, carrying 831 bp of the $\mathrm{N}$ gene coding sequence was subcloned into the NcoI and SacI sites of the plasmid pRTL2. The resulting plasmid, pRTL2:PBNV N-gene (4,731 bp; Online Resource 1 ), which was maintained in E. coli strain $\mathrm{DH} 5 \alpha$, has a double CaMV 35S promoter with a tobacco etch virus (TEV) leader sequence for enhanced expression of the $\mathrm{N}$ gene and was used for transformation by the biolistic method.
For Agrobacterium tumefaciens-mediated genetic transformation, the plasmid pRTL2:PBNV N-gene was digested with $S p h \mathrm{I}$, and the end-filled "N" fragment, along with the promoter $(1,853 \mathrm{bp})$, was subcloned into the endfilled BamHI site of the binary vector pCAMBIA1301 carrying the reporter gene uidA (GUS) with an intron driven by the CaMV $35 \mathrm{~S}$ promoter and nos poly-A terminator sequences along with a CaMV 35S-promoter-driven hygromycin phosphotransferase $(h p t)$ as the selectable marker gene. The new plasmid was designated as pCAMBIA1301:PBNV N-gene (Online Resource 1) and mobilized into A. tumefaciens strain C 58.

Plant material and transformation

Mature seeds of a popular Spanish-type peanut cultivar, JL 24, were used in all experiments. For biolistic-mediated gene transfer (BM), a protocol developed earlier [16] was followed, using the cotyledons and embryonic leaves as explants, which were bombarded with the plasmid pRTL2:PBNV N-gene. The PDS-1000 He system (Bio$\left.\operatorname{Rad}{ }^{\circledR}\right)$ was used for biolistics using gold particle microcarriers $(1 \mu \mathrm{m}$ diameter) at a helium gas pressure of $12 \mathrm{~kg} /$ $\mathrm{cm}^{2}$ and partial vacuum of $600 \mathrm{mmHg}$. A peanut transformation protocol reported previously [30] was followed for the development of transgenic plants via A. tumefaciens-mediated gene transfer (AM). For this, the cotyledon explants from mature pre-soaked seeds were co-cultivated with A. tumefaciens strain $\mathrm{C} 58$ harboring the binary plasmid pCAMBIA 1301:PBNV N-gene.

\section{DNA isolation and PCR analysis}

Molecular studies were carried out to confirm the integration and expression of the introduced genes in the putative transgenic plants. The genomic DNA was isolated from the control (untransformed peanut) and putative transgenic plants using a previously published method [30, 31]. The presence of the hpt and PBNV $\mathrm{N}$ genes in the putative transformants was confirmed by polymerase chain reaction (PCR). A 819-bp region of $h p t$ was amplified using 22-mer oligonucleotide primers ( $h p t$ forward primer, $5^{\prime}$-CGT TAT GTT TAT CGG CAC TTT G-3'; hpt reverse primer, $5^{\prime}$ GGG GCG TCG GTT TCC ACT ATC G-3'). A 585-bp coding region of the $\mathrm{N}$ gene was amplified by using 22 -mer oligonucleotide primers ( $\mathrm{N}$ forward primer, $5^{\prime}$-GCT TGT AAA AGT GGT AAG TAT G-3'; N reverse primer, 5'ATA ATC ATC CAT TGA GAG ACT G-3'). For PCR amplification, the genomic DNA was denatured at $94{ }^{\circ} \mathrm{C}$ for $5 \mathrm{~min}$, followed by denaturation at $94{ }^{\circ} \mathrm{C}$ for $30 \mathrm{~s}$, annealing at $55{ }^{\circ} \mathrm{C}$ for $45 \mathrm{~s}$ and extension at $72{ }^{\circ} \mathrm{C}$ for 1 min for 30 cycles, and then a final elongation step at $72{ }^{\circ} \mathrm{C}$ for $10 \mathrm{~min}$. 
Analysis of gene expression by RT-PCR

For RT-PCR analysis, total RNA was isolated from $100 \mathrm{mg}$ plant tissue by using TRIzol Reagent (Invitrogen, USA). Before synthesizing cDNA, the total RNA was treated with one unit of DNase I and incubated at $37{ }^{\circ} \mathrm{C}$ to eliminate the residual DNA. All of the reagents and conditions used were as described for the Protoscript RT-PCR system for synthesizing the cDNA (New England Biolabs, USA).

\section{Southern blot analysis}

The putative $\mathrm{T}_{0}$ transformants were subjected to Southern blot hybridization by digesting $15 \mu \mathrm{g}$ of the genomic DNA with SphI to release the PBNV N gene, including the promoter and poly A sequences of pRTL2:PBNV N-gene, and with $X b a \mathrm{I}$ to release the PBNV N gene, including the promoter of pCAMBIA:PBNV N-gene. To determine the copy number of the inserts, genomic DNA from the selected events in the $T_{1}$ and $T_{2}$ generations was digested with restriction enzymes that cut only once within the T-DNA region: $X b a \mathrm{I}$ for pRTL2:PBNV N-gene and $S p h \mathrm{I}$ for pCAMBIA:PBNV N-gene. The digested DNA was separated by electrophoresis on a $0.8 \%$ agarose gel and transferred to a nylon membrane (Hybond $\mathrm{N}+$, Amersham) [27]. A PCR-amplified 585-bp fragment of the PBNV N gene was used as a probe after labeling it using the nonradioactive AlkPhos direct system (Amersham). Labeling, hybridization and detection were performed according to the manufacturer's instructions.

\section{DAC-ELISA and western blotting}

DAC-ELISA was carried out to detect the presence of PBNV in transgenic plants that were challenged with the virus in greenhouse experiments, and for the confirmation of natural infection of plants in field experiment studies. The antiserum that was used for western blotting was also used for DAC-ELISA. ELISA tests were carried out once for the infected leaves (after 1 week) and twice for the systemic leaves at 20 and 30 days after inoculation. The standard protocol for direct antigen-coated ELISA was followed [23]. Leaf extracts $(100 \mathrm{mg}$ in $1 \mathrm{ml}$ of $50 \mathrm{mM}$ sodium carbonate buffer, $\mathrm{pH}$ 9.6) were coated onto the wells of an ELISA plate (MaxiSorb, NUNC). PBNV antibodies at a dilution of 1:10,000 (v/v) were added into the wells of the ELISA plate and incubated at $37^{\circ} \mathrm{C}$ for $1 \mathrm{~h}$, followed by incubation with alkaline-phosphatase-conjugated goat anti-rabbit $\operatorname{IgG}$ antibody for $1 \mathrm{~h}$ at $37{ }^{\circ} \mathrm{C}$. p-nitrophenyl phosphate $(0.05 \mathrm{mg} / \mathrm{mL})$ was used as a substrate before incubating the plates at room temperature. The reaction was measured in an ELISA plate reader fitted with a 405-nm filter (SpectraMax Plus microplate reader, Molecular Devices, USA) after addition of the substrate and incubation of the plates for 30,60 or $120 \mathrm{~min}$.

Western blotting was carried out to analyze the expression level of the $\mathrm{N}$ protein, using the protein isolated with TRIzol Reagent (Invitrogen, USA) and PBNV NP antibodies. The total protein was isolated from $500 \mathrm{mg}$ leaf tissue under liquid nitrogen, extracted in $0.5 \mathrm{ml}$ of $0.03 \mathrm{M}$ potassium phosphate buffer (pH 7.5) and $10 \mathrm{mM}$ 2-mercaptoethanol, and centrifuged at $13,000 \mathrm{rpm}$ for $5 \mathrm{~min}$. The protein content in the extract was quantified by the Bradford method (Bradford 1976). Fifty $\mu \mathrm{g}$ of the protein was combined with equal volumes of Laemmli buffer, heat-denatured by boiling in a water bath for $3 \mathrm{~min}$, and separated by $12 \%$ sodium dodecyl sulfate (SDS) polyacrylamide gel electrophoresis (PAGE) followed by immunoblotting onto a nitrocellulose membrane using a semi-dry transfer apparatus [27]. The PBNV NP was detected using a rabbit anti-PBNV NP polyclonal serum as a primary antibody (cross-absorbed polyclonal antibody) and goat anti-rabbit IgG coupled to alkaline phosphatase (Sigma catalog no. A3687) as a secondary antibody. Positive reactions were detected using BCIP-NBT substrate (Sigma catalog no. B1911).

Virus challenge studies

PBNV (ICRISAT isolate) maintained on cowpea plants was used for preparation of the inoculum. Thirty-five $\mathrm{T}_{1}$ transgenic events (20 events produced using BM and 15 produced using AM) were selected for bioassays under P2level greenhouse conditions. Nine seeds from each transgenic event, including a susceptible control, JL 24, were sown and replicated three times. All of the test plants were examined for integration of the transgene by PCR and RTPCR. From each event, six seedlings were selected for inoculation, and the remaining three were kept as uninoculated controls. Virus inoculum was freshly prepared from the infected leaves of cowpea ground in $50 \mu \mathrm{M}$ potassium phosphate buffer at 1:100 dilution (w/v) under ice-cold conditions. The virus inoculum was rubbed onto all of the opened leaves of 8- to 10-day-old test seedlings and rinsed with deionised water after $2 \mathrm{~h}$. All of the pots were maintained at $25{ }^{\circ} \mathrm{C}$ and $75 \% \mathrm{RH}$ in a contained greenhouse for uniform infection. Disease development on the inoculated plants was monitored by DAC-ELISA tests and visual observations. The observations that were recorded included the number and percent of plants infected in each transgenic event, the number of positive plants showing infection, the number of negative plants showing infection, and percentage increase/decrease of disease over the control plants. The plants that did not show infection were advanced to further generations for subsequent evaluations. 
In another set of experiments, $24 \mathrm{~T}_{2}$-generation transgenic lines involving 13 events from $\mathrm{AM}$ and 11 events from $\mathrm{BM}$, including four lines derived from cotyledonory explants and seven derived from embryonic leaf transformation, were used for virus challenge studies with the sap extracts $(1: 50 \mathrm{w} / \mathrm{v})$

\section{Contained field evaluation}

A contained field trial was conducted following approval from the regulatory authorities in India. The field trial was carried out in an isolated area on the farms of ICRISAT, Patancheru, India, during August-December in 2005. Twenty-four $\mathrm{T}_{2}$ transgenic lines that had previously been screened in greenhouse virus-challenge tests were selected and evaluated. The field trial was done using plants from 24 test events and four controls of the non-transgenic peanut variety JL 24 in three replications. Each test event and control had eight seeds per replication and was planted in two rows at a distance of $30 \times 50 \mathrm{~cm}$ in a plot size of $1 \times 1.2 \mathrm{~m}$. Each plot was separated by an $80-\mathrm{cm}$ space, and each replication was separated from the others by 1.0$\mathrm{m}$ alley paths. Two rows of non-transgenic peanut and pearl millet were grown surrounding the experimental areas as trap crops. Observations on the number of diseasefree and diseased plants were recorded periodically. Among the infected plants, the severity of the disease, viz., mosaic leaf symptoms (MLS), apical bud necrosis (ABN), severe necrosis $(\mathrm{SN})$, and mortality $(\mathrm{M})$ were recorded separately for each event and compared with controls. All of the plants, irrespective of symptoms, were tested by ELISA for the presence or absence of PBNV. The observations on disease incidence (DI) were recorded, and analysis of data for the actual number of positive plants in each event was carried out.

\section{Statistical analysis}

Transformation experiments were conducted using a randomized design and repeated at least three times. Data from greenhouse and field studies were analyzed by analysis of variance (ANOVA) to detect significant differences between the means.

\section{Results}

Genetic transformation studies

A total of 900 cotyledon and embryonic leaflet explants of peanut were used in three batches through Agrobacteriumand biolistic-mediated genetic transformation with the PBNV N gene resulting in a total of 375 putative transformants (Online Resource 2). The shoot buds induced in Agrobacterium-mediated gene transfer were initially selected with $2 \mu \mathrm{g} \mathrm{ml}^{-1}$ hygromycin $\left(2 \mu \mathrm{g} \mathrm{ml}^{-1}\right)$ followed by selection on $5 \mu \mathrm{g} \mathrm{ml}^{-1}$ hygromycin during the subsequent subcultures of 2-3 weeks until rooting on the selection-free medium.

For the biolistic-mediated gene transfer, the embryonic leaflet explants cultured on the shoot-induction medium (SIM) turned green and underwent considerable enlargement within 2-3 days of culture, followed by the induction of multiple adventitious shoot buds from the petiolar cut ends in over $80 \%$ the explants within 2-3 weeks. After two subcultures on SIM, explants with the differentiated shoot buds were transferred to shoot elongation medium (SEM) for three subcultures of 4 weeks each. The elongated shoots were rescued at the end of each subculture and transferred to root-induction medium (RIM), where they developed adventitious roots in over $77 \%$ of the elongated shoots within 2 weeks. Since there was no antibiotic marker for selection of the transformed plants, PCR was used to select the transformed plants at the rooting and/or greenhouse stage ( $T_{0}$ generation). The confirmed PCRpositive transgenic events were advanced to further generations.

\section{Molecular analysis}

Putative transformants were screened by PCR and RT-PCR analysis to confirm the presence and expression of transgenes (Online Resource 3). Oligonucleotide primers specific for the $\mathrm{N}$ (585 bp) and hpt (819 bp) genes were amplified to produce a gene fragment of the expected size in 72 and $83 \%$, respectively, of the $\mathrm{T}_{0}$ putative transformants transformed with Agrobacterium tumefaciens. In the other set of transformants that were produced using BM, the transgene amplification indicated a transformation frequency of 39.4 and $44 \%$ in cotyledonary and embryonic leaf explants, respectively. Furthermore, the cDNA isolated from the putative transgenic plants showed amplification of the 585-bp fragment of the $\mathrm{N}$ gene in $62 \%$ of AM transformants. However, a relatively lower number $(26 \%)$ of the transgenic plants derived from BM expressed the transgene, as shown by RT-PCR.

Southern blot analysis was carried out with the selected transformants in the $T_{0}$ and $T_{1}$ generations to ascertain the integration and copy number of the transgenes (Fig. 1a, b). A total of 15 of the 24 tested transgenic plants produced using Agrobacterium-mediated transformation showed hybridization signals, while seven of the 21 plants tested, and 12 of 26 plants tested that were obtained from the BM leaflets and cotyledonary explants, respectively, were positive for the transgene. Moreover, 13 out of the 15 Agrobacterium-mediated transformed plants showed the 


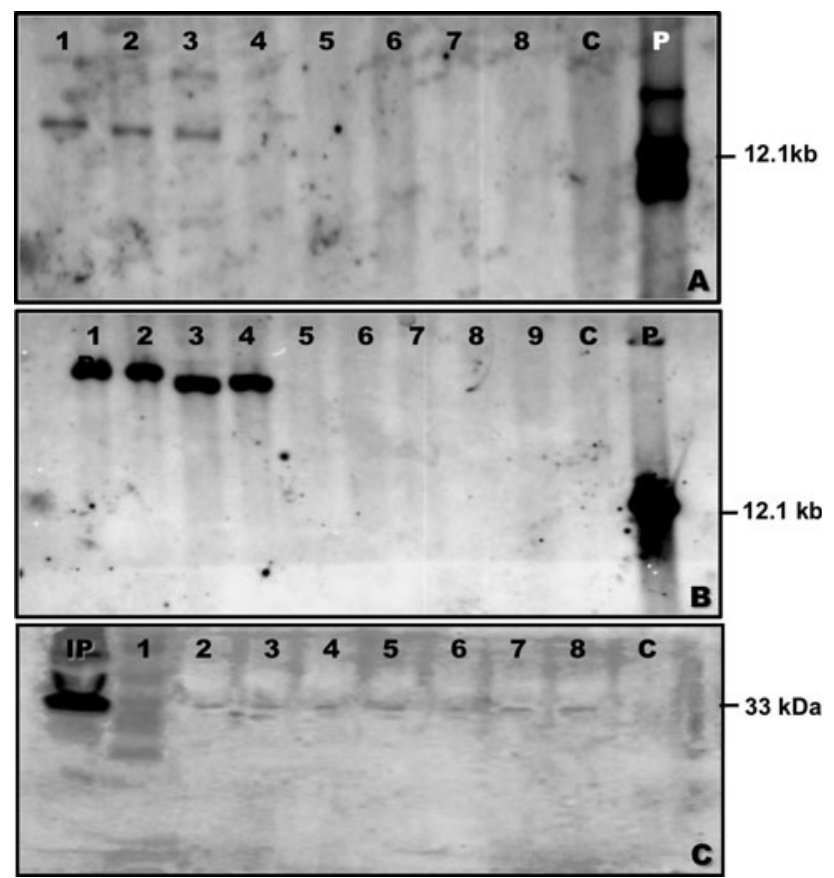

Fig. 1 Molecular characterization of selected $T_{1}$ generation transgenic peanut plants using southern and western blot analysis. a Southern blot of genomic DNA from eight transgenic plant lines that were transformed using biolistics. The DNA was digested with $X b a \mathrm{I}$, which cuts once within the T-DNA region. Lanes 1-8, events $\mathrm{B}-1$, B-4, B-6, B-7, B-10, B-12, B-20, and B-20. Lane $C$ is untransformed control, lane $P$ is the DNA of plasmid pRTL2:PBNVng digested with XbaI; b Southern blot of genomic DNA from nine transgenic plant lines that were transformed with Agrobacterium tumefaciens and digested with $S p h \mathrm{I}$, which cuts once within the T-DNA region. Lanes 1-9, events A-A, A-C, A-K, A-J, A-D, A-E, A-F, A-G, and A-H. Lane $C$ is untransformed control. Lane $P$ is the plasmid DNA of pCAMBIA1301:PBNVng digested with SphI; c Western blot analysis of seven transgenic events. Lane IP is a PBNV-infected sample of peanut, lane 1 is a protein marker, lanes 2-8 are events B-1, A-K, B-11, B-4, A-A, A-C, and A-J. Lane C is the untransformed control

presence of a single site of integration. Analysis of the putative transgenic plants obtained through BM of embryonic leaflets and cotyledonary explants with the plasmid pRTL2:PBNV N gene revealed single-copy integration in five and four plants, respectively.

DAC-ELISA was used with polyclonal antiserum against PBNV (ICRISAT isolate) to detect virus infection in the transgenic plants in the $T_{1}$ generation. All of the 35 tested transgenic events showed varied levels of reaction. The OD readings ranged from 0.125 to 1.472 , compared to a reading of 2.418 for a PBNV-infected peanut plant that was used as a positive control. PBNV N gene expression in the leaf samples was detected in the transformed plants, but not in the untransformed controls, when tested by immunoblot analysis. The PBNV antibodies detected 33-kDa products that had the same electrophoretic mobility as the
PBNV nucleoprotein obtained from infected leaves of wild-type plants (Fig. 1c).

\section{Segregation analysis}

PCR analysis of the transgenes was carried out to characterize the inheritance of the transgene in the $T_{1}$ and $T_{2}$ generations to study the stability of the introduced transgene (Online Resource 4). The results indicated that $>95 \%$ of the plants in the $T_{1}$ and $T_{2}$ generations showed a Mendelian segregation ratio of $3: 1$.

\section{Greenhouse evaluation}

Virus challenge of the transgenic plants using sap extracts prepared from PBNV-infected cowpea plants at a 1:100 dilution was carried out in a contained greenhouse for 35 independent transgenic events in the $\mathrm{T}_{1}$ generation (20 events with $\mathrm{BM}$ ) and 15 events derived from $\mathrm{AM}$ along with untransformed parent JL 24 (Table 1). The results indicated that 16 out of 35 lines $(45.7 \%)$ did not acquire the virus, whereas $19(54.3 \%)$ that acquired the virus showed varied levels of disease intensity. Among the 19 transgenic plant lines that were infected, the disease incidence (DI) in seven ranged from 1 to $25 \%$, in five, it was $26-50 \%$, in six, it was 51-75\%, and in one, it was higher than $75 \%$. Similarly, variations in infectivity were observed amongst the transgenic events, where six lines (30\%) remained infection-free and 14 produced using BM $(70 \%)$ acquired the virus, while ten $(66.6 \%)$ produced using AM were free, and five $(33.3 \%)$ acquired the virus. The disease incidence (DI) was recorded for each event, and the percent increase or decrease and plant mortality over control was calculated.

Based on preliminary screening, 24 transgenic events (13 produced using $\mathrm{AM}$ and 11 produced using $\mathrm{BM}$ ) were selected for the advancement of generation $\left(\mathrm{T}_{2}\right)$ so as to repeat the virus challenge at higher virus concentration [1:50] in the greenhouse (Fig. 2). At this concentration, most of the plants were infected to some extent and showed varying degrees of disease progress and survival (Online Resource 5). Although $100 \%$ of the untransformed control plants died by 3 weeks after inoculation, the transgenic plants did not show any signs of infection until after 2 weeks. The mortality in the transgenic lines due to PBNV infection was recorded as 58.1, 74.8, 84.8, 97 and $100 \%$ in the third, fifth, seventh, ninth, tenth week as well as after ten weeks post-inoculation, respectively, indicating that although two of the transgenic plant lines survived up to 10 weeks post-inoculation, these eventually succumbed to the disease. 
Table 1 Evaluation of 10-day-old transgenic peanut plants $\left(\mathrm{T}_{1}\right.$ generation) under contained greenhouse conditions following challenge with PBNV at a 1:100 dilution

\begin{tabular}{|c|c|c|c|c|}
\hline \multirow[t]{2}{*}{ Sample no. } & \multirow[t]{2}{*}{ Event no. } & \multicolumn{2}{|c|}{$\begin{array}{l}\text { Number of PCR } \\
\text { positive plants }\end{array}$} & \multirow[t]{2}{*}{$\begin{array}{l}\text { Disease } \\
\text { incidence }(\%\end{array}$} \\
\hline & & Inoculated & Infected & \\
\hline 1 & B-1 & 9 & 0 & 0 \\
\hline 2 & B-2 & 8 & 5 & 62.5 \\
\hline 3 & B-3 & 8 & 1 & 12.5 \\
\hline 4 & B-4 & 4 & 1 & 25 \\
\hline 5 & B-6 & 7 & 0 & 0 \\
\hline 6 & B-7 & 5 & 1 & 20 \\
\hline 7 & B-8 & 5 & 0 & 0 \\
\hline 8 & B-9 & 4 & 3 & 75 \\
\hline 9 & B-10 & 2 & 0 & 0 \\
\hline 10 & B-11 & 6 & 2 & 33.3 \\
\hline 11 & B-12 & 2 & 0 & 0 \\
\hline 12 & B-13 & 4 & 2 & 50 \\
\hline 13 & B-14 & 2 & 0 & 0 \\
\hline 14 & B-15 & 3 & 2 & 66.6 \\
\hline 15 & B-19 & 7 & 5 & 71 \\
\hline 16 & B-20 & 6 & 1 & 16.7 \\
\hline 17 & B-21 & 6 & 2 & 33.3 \\
\hline 18 & B-22 & 5 & 4 & 80 \\
\hline 19 & B-26 & 3 & 2 & 66.6 \\
\hline 20 & B-30 & 5 & 3 & 60 \\
\hline 21 & $\mathrm{~A}-\mathrm{A}$ & 4 & 0 & 0 \\
\hline 22 & A-B & 5 & 0 & 0 \\
\hline 23 & A-C & 8 & 0 & 0 \\
\hline 24 & A-D & 6 & 0 & 0 \\
\hline 25 & A-E & 2 & 1 & 50 \\
\hline 26 & $\mathrm{~A}-\mathrm{F}$ & 5 & 2 & 40 \\
\hline 27 & $A-G$ & 6 & 0 & 0 \\
\hline 28 & A-H & 5 & 1 & 20 \\
\hline 29 & A-I & 6 & 1 & 16.7 \\
\hline 30 & A-J & 5 & 1 & 20 \\
\hline 31 & A-K & 3 & 0 & 0 \\
\hline 32 & A-L & 2 & 0 & 0 \\
\hline 33 & A-M & 3 & 0 & 0 \\
\hline 34 & A-N & 4 & 0 & 0 \\
\hline 35 & A-P & 4 & 0 & 0 \\
\hline Control & JL 24 & 6 & 4 & 66.6 \\
\hline
\end{tabular}

Disease incidence was measured for 2-7 weeks post-inoculation

Evaluation under field conditions

Twenty-four transgenic lines in the $\mathrm{T}_{2}$ generation (13 AM and $11 \mathrm{BM}$ ) that showed integration of the PBNV $\mathrm{N}$ gene and remained either infection-free or had less viral infection following virus challenge tests I and II were selected for evaluation under natural field conditions (Fig. 3). The initial mosaic symptoms were observed in seedlings from 2 to 3 weeks after germination, and the disease incidence (DI) was monitored and recorded fortnightly until the plants reached maturity. The disease incidence (DI) in the untransformed control plants was $85.4 \%$, with severity of 16.6, 35.4, 24 and 9.4\% of MLS, ABN, SN and mortality, respectively. Among the test events, the disease incidence and intensity were variable, where the disease incidence (DI) of the test events was measured on a 0-4 scale, viz., 0 (Nil), 1 (1-25\%), 2 (26-50\%), 3 (51-85\%) and 4 (>85\%, maximum disease incidence as untransformed control).

The disease incidence (DI) analyzed on the basis of transformation method indicated that in the transgenic events obtained through BM, one had a lower disease incidence (1-25\%), two had a 26-50\% disease incidence, seven were in a range of 51-85\% disease incidence and one was above $85 \%$. However, none of the events from AM were in the range of $1-25 \%$ disease incidence, while three had 26-50\% disease incidence, six had 51-85\% disease incidence, and four had a disease incidence of $>85 \%$. Based on these results, nine (from both BM an AM) with a lower disease incidence (35-80\%) over the untransformed controls were identified as better performers under field evaluation (Table 2; Fig. 3). Overall, in the field evaluation studies, only one transgenic plant line showed a modest reduction in disease incidence $(17.7 \%)$ when compared to the other five that showed 42-51\% reduction in disease incidence and to untransformed controls. Also, based on the percent disease resistance (DR), calculated in terms of disease incidence and healthy plants over the control, the progeny of event GNPBNV-B-1 was ranked as best $(67 \%)$, followed by GNPBNV-A-K (43.7\%) and GNPBNV B-11 (41.7\%) (Fig. 4).

\section{Discussion}

Introduction of the viral $\mathrm{N}$ gene by genetic transformation is a rapid and effective means to generate novel resistance against viral diseases in crop plants. In the present study, transgenic peanut plants were developed for resistance against PBND by introducing the PBNV N gene using two methods of gene transfer. The resulting transgenic plants were analyzed molecularly as well as in virus bioassays under greenhouse and field conditions. A total of 15 transgenic plants were generated using Agrobacterium-mediated transformation [30, 31], resulting in $43 \%$ regeneration frequency and a transformation frequency of over $72 \%$. The transformation procedure based on biolistics used for direct gene transfer resulted in overall shoot regeneration and transformation frequencies of 47 and $39.4 \%$, respectively, with cotyledonary explants, and 34 and $44 \%$, 

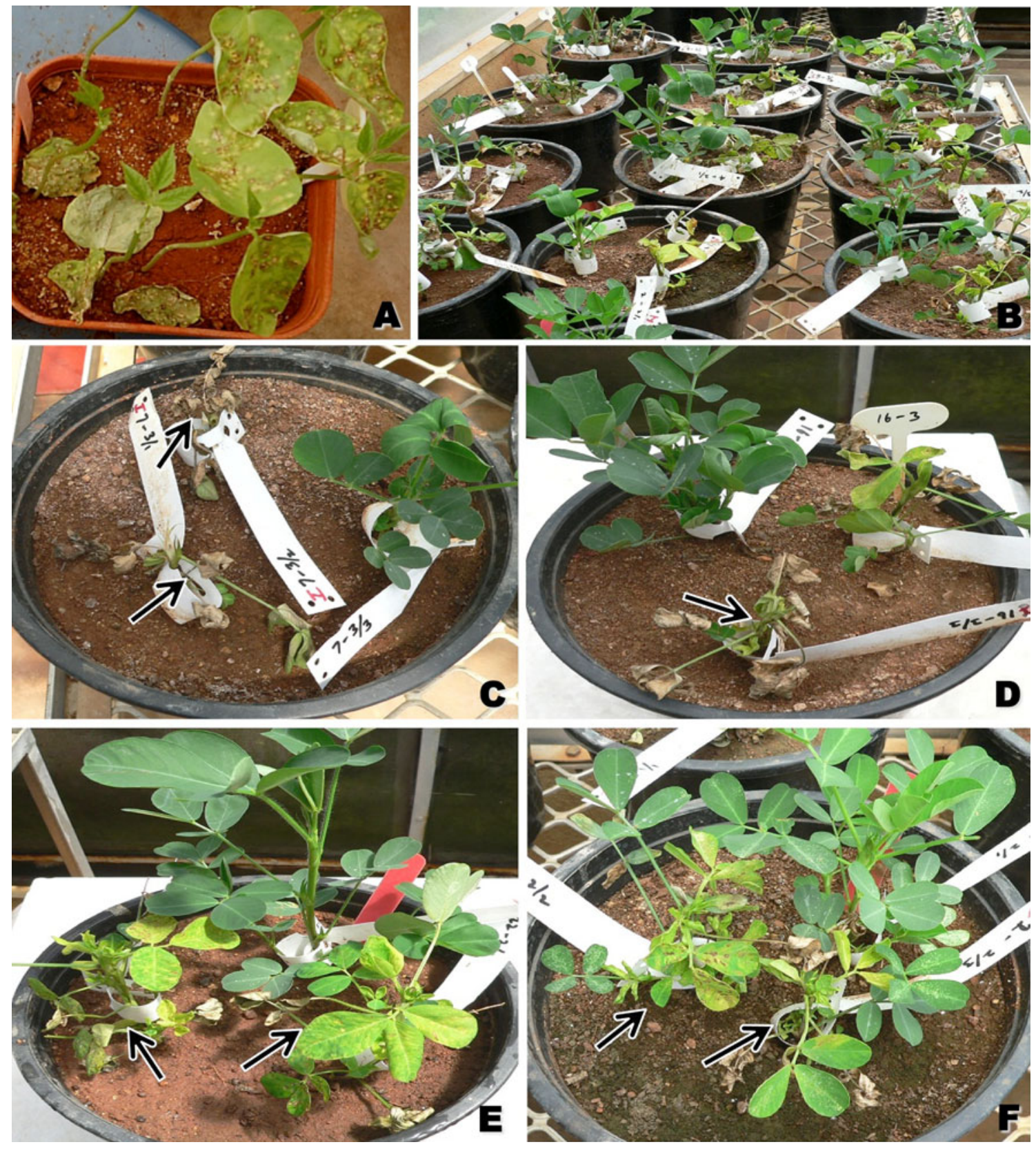

Fig. 2 Evaluation of transgenic peanut plants in a contained greenhouse by challenge with the PBNV inoculum at 1:50 dilution. a Indicator cowpea plants showing severe necrotic symptoms within 1 week after inoculation, $\mathbf{b}$ transgenic plants showing varied levels of disease incidence, $\mathbf{c}$ seedlings of untransformed control plants

respectively, with embryonic leaflets. Also, the transformation efficiency obtained in this study by the biolistic method is the highest reported so far when compared to previous reports $[2-4,21,29,36]$, thereby indicating that embryonic leaflets and half cotyledons of peanut can also be used as suitable explants for transformation of peanut by the biolistic method. showing mortality at 2 weeks after inoculation (arrow), $\mathbf{d}$ inoculated seedlings of transgenic plant B-9 showing mortality (arrow) at 5 weeks after inoculation, e, $\mathbf{f}$ transgenic plnats A-A and B-1, showing survival at 9 weeks after inoculation

Using both direct and indirect methods for peanut transformation, out of the 35 putative transgenic events tested in the $\mathrm{T}_{0}$ generation, 22 had single-copy inserts. The number of transgenic events carrying the single copy inserts was lower in the ones produced by the biolistic method when compared to Agrobacterium-mediated transformation. High copy number has been known to be a 

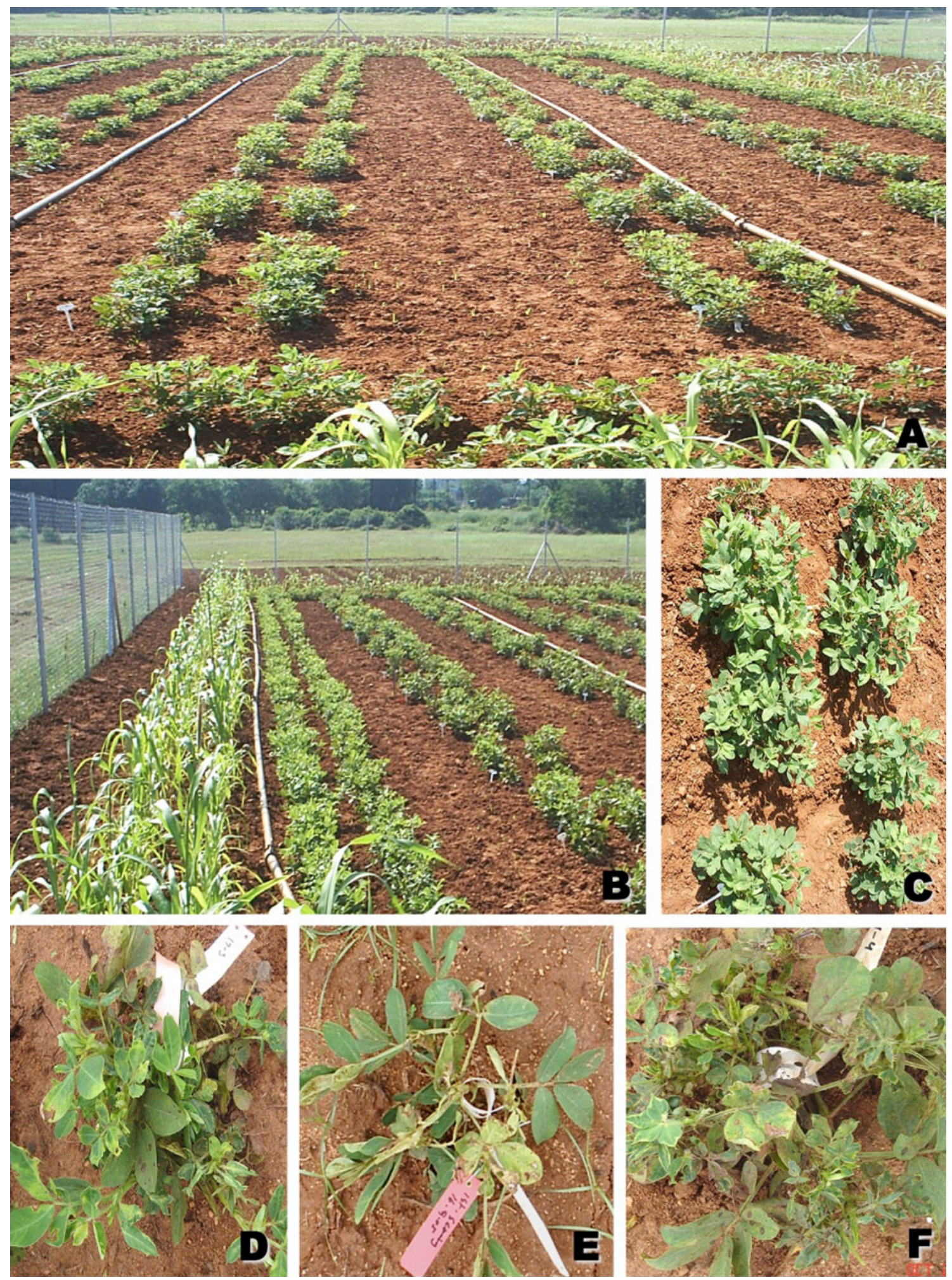

Fig. 3 Evaluation of resistance of selected transgenic peanut plants to natural infection by PBNV in a contained field. $\mathbf{a}, \mathbf{b}$ General view of the field experiment with pearl millet as a border crop and untransformed peanut plants raised in two rows outside the plot. c A transgenic plant line (B-1) showing healthy and disease-free plants. d, e Various disease symptoms of PBND observed on test plants. d mosaic, e apical bud necrosis, $\mathbf{f}$ severe necrosis 
Table 2 Evaluation of transgenic plants of $T_{2}$ generation peanut by PBNV challenge under contained field conditions $(n=8)$
* MLS mild leaf symptoms, $A B N$ apical bud necrosis, $S N$ severe necrosis, $M$ mortality

\begin{tabular}{|c|c|c|c|c|c|c|}
\hline \multirow[t]{2}{*}{ Event } & \multirow[t]{2}{*}{ DI } & \multicolumn{4}{|c|}{ Disease severity $(\%)^{*}$} & \multirow{2}{*}{$\begin{array}{l}\text { Relative DI reduction } \\
\text { over control }(\%)\end{array}$} \\
\hline & & MLS & $\mathrm{ABN}$ & SN & M & \\
\hline PB (B)-1 & 17.7 & 5.9 & 5.9 & 5.9 & 0 & 79.3 \\
\hline PB (B)-3 & 53.3 & 13.3 & 26.7 & 13.3 & 0 & 37.6 \\
\hline PB (B)-4 & 46.2 & 15.4 & 7.7 & 23.1 & 0 & 45.9 \\
\hline PB (B)-6 & 54.1 & 17.7 & 17.7 & 17.7 & 0 & 37.8 \\
\hline PB (B)-7 & 56.2 & 12.5 & 25 & 12.5 & 6.2 & 34.2 \\
\hline PB (B)-10 & 75.0 & 6.3 & 37.5 & 31.2 & 0 & 11.9 \\
\hline PB (B)-11 & 43.70 & 18.7 & 25 & 0 & 0 & 48.8 \\
\hline PB (B)-12 & 86.70 & 13.3 & 33.3 & 40.1 & 0 & - \\
\hline PB (B)-14 & 69.60 & 11.8 & 35.3 & 23.5 & 0 & 17.1 \\
\hline PB (B)-20 & 81.80 & 22.2 & 44.5 & 11.1 & 0 & 8.9 \\
\hline PB (B)-21 & 72.20 & 11.1 & 33.3 & 22.2 & 5.6 & 15.4 \\
\hline PB (A)-A & 46.20 & 15.4 & 23.1 & 7.7 & 0 & 15.5 \\
\hline PB (A)-B & 75 & 16.7 & 25 & 33.3 & 0 & 45.9 \\
\hline $\mathrm{PB}(\mathrm{A})-\mathrm{C}$ & 50 & 14.3 & 28.6 & 7.1 & 0 & 41.5 \\
\hline PB (A)-D & 100 & 29.4 & 35.3 & 35.3 & 0 & - \\
\hline PB (A)-E & 83.70 & 16.7 & 27.8 & 38.8 & 0 & 2.5 \\
\hline PB (A)-F & 82.30 & 23.5 & 29.4 & 23.5 & 5.9 & 3.6 \\
\hline PB (A)-G & 88.90 & 11.1 & 27.8 & 44.4 & 5.6 & - \\
\hline PB (A)-H & 100 & 13.3 & 33.3 & 53.4 & 0 & - \\
\hline PB (A)-I & 87.80 & 22.2 & 44.5 & 11.1 & 0 & 8.9 \\
\hline PB (A)-J & 52.90 & 11.8 & 23.5 & 17.6 & 0 & 38.0 \\
\hline PB (A)-K & 41.70 & 16.7 & 25 & 0 & 0 & 51.2 \\
\hline PB (A)-L & 88.90 & 16.8 & 33.3 & 38.8 & 0 & - \\
\hline $\mathrm{PB}(\mathrm{A})-\mathrm{N}$ & 70.50 & 17.6 & 35.3 & 17.6 & 0 & 17.4 \\
\hline Control & 85.40 & 16.6 & 35.4 & 24 & 9.4 & - \\
\hline
\end{tabular}

common feature associated with the biolistic method of transformation [12]. Nevertheless, upon advancement of generations, all the 16 transgenic plants $(100 \%)$ in the $\mathrm{T}_{1}$ generation and 23 out of $24(96 \%)$ in $\mathrm{T}_{2}$ generation followed the Mendelian segregation ratio of $3: 1$. Based on these results, it is evident that the transgene was transmitted to and expressed in the successive progeny.

The virus challenge experiments with $T_{1}$ generation transgenic plants of peanut revealed that 16 of the 35 tested transgenic plant lines $(45.7 \%)$ did not acquire the virus under the conditions of the greenhouse assays. However, in the $\mathrm{T}_{2}$ generation, only three transgenic events, viz., GNPBNV B1-2, GNPBNV AK-3 and GNPBNV B11-2, showed a 40 to $67 \%$ decrease in disease incidence and were considered to be superior under greenhouse conditions. These results indicated that 19 out of 35 lines could be infected at a virus dilution of 1:100, whereas at a 1:50 dilution, all of the transgenic plants tested were infected. However, the disease severity varied among the transgenic events at different periods post-inoculation. Most of the plants survived up to 3-9 weeks post-inoculation (WPI), but only two survived up to ten WPI when compared to the untransformed controls, which survived only for two WPI. Based on these preliminary data, the delay in expression of symptoms and mortality was attributed to the resistance gained due to the presence of the transgene in these plants.

Nevertheless, for subsequent contained field evaluations, a high level of natural infection of PBNV prevailed during the test period, which was an added advantage for screening for resistance. Under field conditions, while three transgenic lines (GNPBNV-B-1-2-1, GNPBNV-AK-3-4 and GNPBNV B-11-2-3) showed a considerable reduction in disease incidence, only one (GNPBNV-B-12-1) showed less than $20 \%$ disease incidence and emerged as somewhat resistant to PBND. These variations among the transgenic events under field conditions were comparable to the results of virus challenge test at 1:50 dilution carried out under greenhouse conditions, thereby indicating that the highly efficient mechanical inoculation is likely to introduce a greater amount of virus inoculum when compared to thrips-mediated natural infection [39]. Nevertheless, the transgenic plants in our study had fewer necrotic spots than did controls grown under identical conditions. 


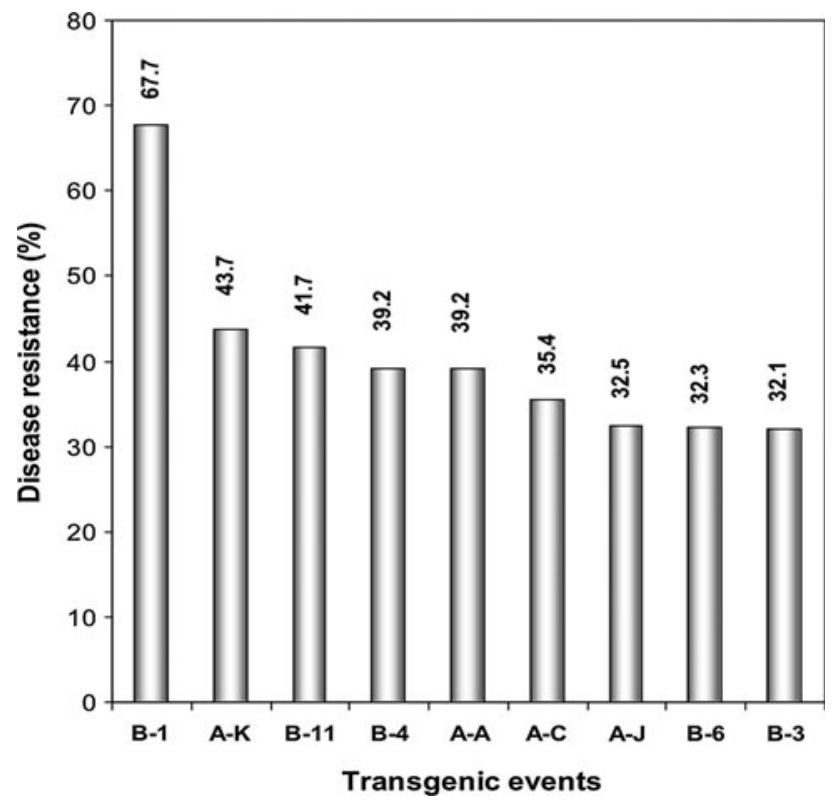

Fig. 4 Percentage of relative disease resistance in $T_{2}$ generation transgenic plants. The selected transgenic plant lines showed improved resistance to PBND during contained field-testing when compared to the untransformed controls. The untransformed controls were considered susceptible to PBND

During the course of the investigation presented here, although most of the transgenic plants were confirmed to express the transgene, only three lines (GNPBNV-B-1-2-1, GNPBNV-A-K-3-4 and GNPBNV B-11-2-3) in the $\mathrm{T}_{2}$ generation eventually exhibited a considerable level of resistance, while others showed susceptibility or low levels of resistance under greenhouse and field conditions. This indicates the possible occurrence of transgene silencing in these transgenic plants. Occurrence of transgene silencing has also been reported previously in transgenic sorghum plants obtained by the biolistic method of transformation [9]. These results are also in agreement with previous findings in which low to medium expression levels of the viral transgenes in peanut have been observed [15, 18, 39]. Also, progeny of the transgenic peanut plants developed for resistance to alfalfa mosic virus (AMV) accumulated detectable amounts of the viral coat protein but remained susceptible to the virus under greenhouse conditions [35]. This unexpected behavior and considerable variation in the expression of transgenes could not be attributed only to the copy number but were also influenced by other factors such as the strength of the promoter, epigenetic factors, positional effect, inherent host genome, pre- and post-transcriptional, and translational processes [19, 32].

This is the first report on generating transgenic peanut plants exhibiting a modest tolerance to PBND both under greenhouse and field conditions, where one transgenic event showed partial resistance $(<20 \%$ disease incidence,
DI) under natural infection under field conditions. This apparent lack of resistance to PBND in the transgenic plants could be due to the presence of RNA silencing suppressor gene, (NSs) in the PBNV genome that render the PBNV $\mathrm{N}$ gene ineffective [14, 17, 33]. However, considering the unexpectedly low frequency of virusresistant plants throughout the challenge experiments, it is concluded that an alternate strategy based on RNA-interference-mediated gene silencing (antisense and hairpin RNA) could be a potential tool for achieving more efficient protection against PBNV.

Acknowledgments We thank T. Swami Krishna, D. Pandary, Md. Yousuf, and C. Lakshminarayana for excellent technical assistance during this study. SCR would like to thank the Jawaharlal Nehru Technological University, Hyderabad, for providing an opportunity to register for the Ph.D. program.

\section{References}

1. Able JA, Rathu S, Godwin ID (2001) The investigation of optimal bombardment parameters for transient and stable transgene expression in sorghum. In Vitro Cell Dev Biol Plant 37:341-348

2. Bhatnagar-Mathur P, Anjaiah V, Kirti PBK, Sharma KK (2008) Agrobacterium-mediated genetic transformation of peanut. In: Kirti PBK (ed) Handbook of new technologies for genetic improvement of legumes. CRC Press, Boca Raton, pp 227-251

3. Brar GS, Cohen BA, Vick XX, Johnson GW (1994) Recovery of transgenic peanut (Arachis hypogea L.) plants from elite cultivars using ACCELL technology. Plant J 5:745-753

4. Clemente TE, Robertson D, Isleib TG, Beute MK, Weissinger AK (1992) Evaluation of peanut (Arachis hypogaea L.) leaflets from mature zygotic embryos as recipient tissue for biolistic gene transfer. Transgenic Res 1:275-284

5. Daniel S (2002) Development of transgenic plants of groundnut for induced resistance groundnut rosette disease. Ph.D. thesis, Jawaharlal Nehru Technological University (JNTU), Hyderabad, pp 118

6. Dietzgen RG, Mitter N, Higgins CM, Hall R, Teycheney PY, Cruinkshank A, Hapsoro D, Suderson O (2004) Harnessing RNA silencing to protect peanuts from stripe disease. In: New directions for a diverse planet. Proceedings of fourth international crop science congress. 26 Sept-1 Oct 2004, Brisbane

7. Dwivedi SL, Nigam SN, Reddy DVR, Reddy AS, Ranga Rao GV (1995) Progress in breeding groundnut varieties resistant to bud necrosis virus and its vector. In: Buiel AAM, Parlevliet JE, Lenne JM (eds) Recent studies on peanut bud necrosis disease. ICRISAT, Patanchuru, p 35

8. Gielen JJL, De Haan P, Kool AJ, Peters D, Van Grinsven MQJM, Goldbach RW (1991) Engineered resistance to spotted wilt virus, a negative-strand RNA virus. Biotechnology 9:1363-1367

9. Girijashankar V, Sharma HC, Sharma KK, Swathisree V, Sivarama Prasad L, Bhat BV, Royer M, Secundo BS, Lakshmi Narasu M, Altosaar I, Seetharama N (2005) Development of transgenic sorghum for insect resistance against the spotted stem borer (Chilo partellus). Plant Cell Rep 24:513-522

10. Grumet R (1994) Development of virus resistant plants via genetic engineering. Plant Breed Rev 12:47-79

11. Higgins CM, Hall RM, Mitter N, Cruickshank A, Dietzgen RG (2004) Peanut stripe potyvirus resistance in peanut (Arachis 
hypogaea L.) plants carrying viral coat protein gene sequences. Transgenic Res 138:1-9

12. Jorgensen R, Cluster P, Que Q, English J, Napoli C (1996) Chalcone syntheses co-suppression phenotypes in Petunia flowers: comparison of sense vs. antisense constructs and simple vs. complex T-DNA sequences. Plant Mol Biol 31:957-973

13. Kim JW, Sun SSM, German TL (1994) Disease resistance in tobacco and tomato plants transformed with the tomato spotted wilt virus nucleocapsid gene. Plant Dis 78:615-621

14. Kormelink R, Kitajima EW, De Haan P, Zuidema D, Peters D (1991) The nonstructural protein (NSs) encoded by the ambisense S RNA segment of tomato spotted wilt virus is associated with fibrous structures in infected plant cells. Virology 181:459-468

15. Li ZJ, Jarret RL, Demski JW (1997) Engineered resistance to tomato spotted wilt virus in transgenic peanut expressing the viral nucleocapsid gene. Transgenic Res 6:297-305

16. Livingstone DM, Birch RG (1995) Plant regeneration and microprojectile mediated gene transfer in embryonic leaf lets of peanut (Arachis hypogaea L.). Aust J Plant Physiol 22:585-591

17. Lokesh B, Rashmi PR, Amruta BS, Srisathiyanarayanan D, Murthy MRN, Savithri HS (2010) NSs encoded by groundnut bud necrosis virus is a bifunctional enzyme. PLoS ONE 5:e9757. doi: 10.1371/journal.pone.0009757

18. Magbabua ZV, Wilde HD, Roberts JK, Chowdhury K, Abad J (2000) Field resistance to tomato spotted wilt virus in transgenic peanut (Arachis hypogaea L) expressing an antisense nucleocapsid gene sequence. Mol Breed 6:227-236

19. Matzke MA, Matzke AJM (1995) How and why do plants inactive homologous (trans) genes? Plant Physiol 107:679-685

20. Nwokolo E (1996) Peanut (Arachis hypogaea L.). In: Nwokolo E, Smartt J (eds) Food and feed from legumes and oilseeds. Chapman and Hall, New York, pp 49-63

21. Ozias-Akins P, Schmall JA, Anderson WF, Singsit C, Clemente TE, Adang MJ, Wessinger AK (1993) Regeneration of transgenic peanut plants from stably transformed embryogenesis callus. Plant Sci 93:185-194

22. Pang SZ, Bock JH, Gonsalves C, Slightom JL, Gonsalves D (1994) Resistance of transgenic Nicotiana benthamiana plants to tomato spotted wilt and impatiens necrotic spot topsoviruses: evidence of involvement of the $\mathrm{N}$ protein and the $\mathrm{N}$ gene RNA in resistance. Phytopathology 84:243-249

23. Reddy AS, Prasad Rao RDVJ, Thirumala Devi K, Reddy SV, Mayo MA, Roberts I, Satyanarayana T, Subramaniam K, Reddy DVR (2002) Occurrence of Tobacco streak virus on peanut (Arachis hypogaea L.) in India. Plant Dis 86:173-178

24. Reddy DVR (1991) Groundnut viruses and virus diseases; distribution, identification and control. Ann Rev Plant Pathol 70:665-667

25. Reddy DVR, Buiel AAM, Satyanarayana T, Dwivedi SL, Reddy AS, Ratna AS, Vijaya Lakshmi K, Ranga Rao GV, Naidu RA, Wightman JA (1995) Peanut bud necrosis disease: an overview. In: Buiel AAM, Parlevliet JE, Lenne JM (eds) Recent studies on peanut bud necrosis disease. Proceedings of a meeting at ICRISAT Asia Center, Patancheru, pp 3-7
26. Reddy DVR, Ratna AS, Sudarshan MR, Poul F, Kiran Kumar I (1992) Serological relationships and purification of bud necrosis virus, a tospovirus occurring in peanut (Arachis hypogaea L.) in India. Ann Appl Biol 120:279-286

27. Sambrook J, Fritsch EF, Maniatis T (1989) Molecular cloning: a laboratory manual, 2nd edn. Cold Spring Harbor Laboratory press, New York

28. Sathyanarayana T, Mitchell SE, Reddy DVR, Brown S, Kresovich S, Jarret R, Naidu RA, Demski J (1996) Peanut bud necrosis tospovirus S RNA: complete nucleotide sequence, genome organization and homologous to other tospoviruses. Arch Virol 141:85-98

29. Schnall JA, Weissinger AK (1995) Genetic transformation in Arachis hypogaea L. In: Bajaj YPS (ed) Biotechnology in agriculture and forestry, vol 34. Springer, Berlin

30. Sharma KK, Anjaiah V (2000) An efficient method for the production of transgenic plants of peanut (Arachis hypogaea L) through Agrobacterium tumefaciens mediated genetic transformation. Plant Sci 159:7-19

31. Sharma KK, Bhatnagar-Mathur P (2006) Peanut (Arachis hypogaea L.). In: Kan W (ed) Agrobacterium protocols (methods in molecular biology) vol 44. Humana Press Inc., Totowa, pp 347-358

32. Stam M, Mol JN, Kooter JM (1997) The silence of genes in transgenic plants. Ann Bot 79:3-12

33. Takeda A, Sugiyama K, Nagano H, Mori M, Kaido M (2002) Identification of a novel RNA silencing suppressor, NSs protein of tomato spotted wilt virus. FEBS Lett 532:75-79

34. Vaira AM, Semeria L, Crespi S, Lisa V, Allavena A, Accotto GP (1995) Resistance to topsoviruses in Nicotiana benthamiana transformed with the $\mathrm{N}$ gene of tomato spotted wilt virus: correlation between transgene expression and protection in primary transformants. Mol Plant Microbe Interact 8:56-73

35. Vaughan GMT, Pither-Joyce MD, Cooper PA, Russel AC, Goulden DS, Butter R, Grant JE (2001) Partial resistance of transgenic pea to Alfa Alfa Mosaic Virus under green house and field conditions. Crop Sci 41:846-853

36. Venkatachalam P, Geeta N, Khandelwal A, Shaila MS, Lakshmi Sita G (2000) Agrobacterium-mediated genetic transformation and regeneration of transgenic plants from cotyledon explants of groundnut (Arachis hypogaea L.) via somatic embryogenesis. Curr Sci 78:1130-1136

37. Venkatesan S, Raja JAJ, Maruthasalam S, Kumar KK, Ramanathan A, Sudhakar D, Balasubramanian P (2009) Transgenic resistance by $\mathrm{N}$ gene of a Peanut bud necrosis virus isolate of characteristic phylogeny. Virus Genes 38:445-454

38. Wightman JA, Ranga Rao GV, Vijaya Lakshmi K (1995) Thrips palmi, general pest and vector of some tospoviruses in Asia. In: Buiel AAM, Parlevliet JE, Lenne JM (eds) Recent studies on peanut bud necrosis disease. ICRISAT, Patancheru, p 35

39. Yang H, Ozias-Akins P, Culbreath AK, Gorbet DW, Weeks JR, Amndal B, Pappu HR (2004) Field evaluation of Tomato spotted wilt virus resistance in transgenic peanut (Arachis hypogaea L.). Plant Dis 88:259-264 